\title{
Status of Fisheries in Republic of Malawi, Central Africa
}

\author{
Vaitheeswaran Thiruvengadam* \\ Department of Aquaculture, DMI St. John the Baptist University, Central Africa
}

*Corresponding author: Vaitheeswaran Thiruvengadam, Lecturer, Department of Aquaculture, DMI St. John the Baptist University, Mangochi Campus, Republic of Malawi, Central Africa.

To Cite This Article: Vaitheeswaran Thiruvengadam. Status of Fisheries in Republic of Malawi, Central Africa. Am J Biomed Sci \& Res. 2019 2(2). AJBSR.MS.ID.000576. DOI: 10.34297/AJBSR.2019.02.000576

Received: March 29, 2019 | Published: April 01, 2019

\section{Editorial}

David Livingstone first saw Lake Nyassa, now Lake Malawi, in 1859 and was bewitched by its beauty. "The lake of stars", he called it, as a myriad winking galaxy glittered from the crystal facets of the water. The lake gathers most of its water from rivers to the west, and has only one outlet, the Shire River. The Shire drains the lake at its most southern point, opposite the town of Mangochi. Established on the east bank in 1891, the little town was a garrison against slave traffic. Boadzulu, a rocky island off Club Makokola, mentioned by David Livingstone in his Narrative of an Expedition to the Zambezi and its Tributaries and the Discovery of Lakes Nyassa and Chilwa (London, 1865), is well worth the short cruise to see giant monitor lizards basking on the rocks. The population of fish eagles on this shoreline is said to be the densest in Africa and their haunting cries are heard everywhere, dawn till dusk.

The third largest lake in Africa, and one of the deepest in the world, its water is particularly pure. Fish prefer the shallower, southern end, so it's no surprise that the human population is denser in the south. Here too, the brightly coloured cichlid fishes, mbuna, abound, making rocky island shores an open-air aquarium for snorkelers and scuba divers. Long and lithe, Lake Malawi was once known as the "calendar lake", measuring 365 miles in length and 52 miles across at its widest point. Tropical Lake Malawi is the southernmost of the East African Rift Valley lakes. It is $560 \mathrm{~km}$ long, $40-70 \mathrm{~km}$ wide and $22,490 \mathrm{~km}^{2}$ in area, with a terrestrial watershed of 75,300 km2 and a maximum depth of $700 \mathrm{~m}$. It is a popular hot location with the cleanest beaches on Lake Malawi with its deep and crystal waters that boast a beautiful fish sanctuary and a delight to divers. The water is high transparency and low nutrient concentration in the upper layer [1], the lake was considered oligotrophic. Seventy percent of Lake Malawi coastline consists, generally, of sloping sandy beaches, vegetated areas and swamp. The selected practices viz., Line hauler, Usage of ecofriendly hook (relevant hook size), Size of the hooks (9), Adoption of advanced hook type (other than 'J' type hook), Adoption of monofilament, correct float material. The artisanal fishery about Seventy-five percentage of Lake Malawi catch from Malawian waters the fishery operating from villages spread along the lakeshore. The five basic types of fishing gears viz. beach seine nets, open-water seine nets, gillnets, hooks and traps.

Most of the fish species in Lake Malawi are endemic. The fisheries sector in Malawi is divided into two groups: capture fisheries and aquaculture. The capture fisheries sector is the major sector. The main target fish species for the artisanal fisheries, depending on the fishing gear, are chambo (Oreochromis species), Kambuzi (Haplochromis species), Usipa (Engraulicypris sardella), Utaka (Copadichromis species), Kampango (Bargrusmeridionalis) and Mlamba (Clariid gariepinus). The main fishing gears are gillnets, chambo seine nets, kambuzi seine nets, nkacha seine nets, chilimira seine nets, longlines, handlines and fish traps. Catches by fish species in 2003, indicated that Utaka (Haplochromis spp.) contributed the highest Chambo (Oriochromis spp.) second Usipa (Engraulicypris sardella).

The Republic of Malawi, resources assessment of finfish and shell fisheries biodiversity in Malawi epochs hindmost to prompt majestic times when the focus was on fisheries taxonomical studies of preserved collections in natural history museums. Meanwhile 1939, fisheries and aquaculture research was conducted to inform economic exploitation of finfish and shellfish stocks and to achieve scientific objectives on generating new technological knowledge on Malawi's distinctive finfish and shellfish fisheries biodiversity. In the 1970s, fish provided 70 per cent of animal protein intake of the Malawian population and 40 per cent of total protein supply for the country. The fishing areas include Lake Malawi, which is the biggest lake in the country. 
The Malawi fisheries division recognizes the important food security and economic contributions of the fisheries and aquaculture sector in Malawi. The fisheries sector directly employed was estimated 61,143 fishes in 2016 with over half a million people engaged in ancillary activities, viz., like fish processing, fish marketing, boat building and engine repair. According to the Southern African Development Community, (2016) the lake of Malawi have third largest catches was estimated in Africa, 1,49,315 ton/annually, lake Chilwa was estimated 20,000 annual catches. SADA (2016), have reviewed that the lake of Chilwa, Malawi, have 170,000 people working as a fulltime basis, nearly $35 \%$ fishers, $50 \%$ fish processors and traders, $15 \%$ engaged in ancillary activities. In 2016, the production of fish amounted to 157,267 tones with a beach or landed value of MK129.74 billion (USD172.74) [3]. Eightyseven percentage of fish landings come from small scale fishers, in which use a variety of fishing gear including beach seines, open water seines, gill-nets, fish traps and hooks.

\section{Specific Objectives}

To promote fisheries and aquaculture research in Southeast of Arm of Malawi Lake. The commercial species, viz., Oreochromis shiranus, T. rendalli, O. karongae and common carp O. niloticus, domestication of new local species Bagrus meidionali.

a. To Sea ranching of chambo commercial species b. To determine the species composition of population dynamics and stock assessment, distribution and abundance of fish in Southeast arm of lake Malawi

c. To monitor changes in the species composition, size distribution, and catch rates in the exploited areas and to increase the knowledge base of the resource

d. To control prolific breeding of tilapia/chambo by sex reversal

e. To increase fish production in Malawi Lake

The prioritized research areas, academic research institutions in Republic of Malawi will continue to support generation of knowledge, innovation and solutions and to hence the development of fisheries zone. Further to implementation of well-targeted and good quality research to inform policy and decision-making processes for sustainable development.

\section{References}

1. Harvey A Bootsma, Robert E. Hecky (2003) A Comparative Introduction to the Biology and Limnology of the African Great Lakes. J Great Lakes Res 29(2): 3-18.

2. ADC Fisheries Fact Sheet. 1(3): 1-10.

3. National Fisheries and Aquaculture Research Agenda. (2017-2022) p.1-32. 